\title{
Article
}

\section{Sufis, Salafis and Islamists: The Contested Ground of British Islamic Activism [Book Review]}

Morris, Carl

Available at http://clok.uclan.ac.uk/21367/

Morris, Carl ORCID: 0000-0001-6698-3116 (2018) Sufis, Salafis and Islamists: The Contested Ground of British Islamic Activism [Book Review]. Islam and Christian-Muslim Relations, 29 (3). pp. 402-404. ISSN 0959-6410

It is advisable to refer to the publisher's version if you intend to cite from the work. http://dx.doi.org/10.1080/09596410.2018.1429375

For more information about UCLan's research in this area go to http://www.uclan.ac.uk/researchgroups/ and search for < name of research Group>.

For information about Research generally at UCLan please go to http://www.uclan.ac.uk/research/

All outputs in CLoK are protected by Intellectual Property Rights law, including Copyright law. Copyright, IPR and Moral Rights for the works on this site are retained by the individual authors and/or other copyright owners. Terms and conditions for use of this material are defined in the policies page.

\section{CLoK}

Central Lancashire online Knowledge www.clok.uclan.ac.uk

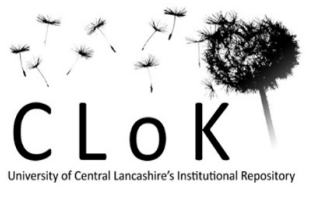




\section{Review of Hamid, Sadek (2016) Sufis, Salafis and Islamists: The Contested Ground of British Islamic Activism. London: I.B. Tauris.}

\section{Carl Morris - University of Central Lancashire}

One of the more dispiriting ironies for public debates concerning the 'problem' of political Islam in Britain has been the extent to which labels are lazily applied, or more cynically hijacked, within mainstream political discourse. A vacuous rhetoric often pervades policy proscriptions and national conversations, whereby political or activist Muslim currents seemingly blur into the hazy morass of an ill-defined - though threateningly charged - blanket-labelled 'Islamism'. Generating a torpid heat, with little insight, these debates rarely attempt to recognise the complexity or mutable diversity of Islamic revival movements in Britain, instead often setting them within a framework governed by a 'pathways to extremism' leitmotif. It is this misapprehension that Sadek Hamid so brilliantly tackles in his book, Sufis, Salafis and Islamists: The Contested Ground of British Islamic Activism.

The foci of the book are four important British Muslim activist movements/organisations: Young Muslims UK, Hizb ut-Tahrir, Salafi-oriented trends and the Sufi 'Traditional Islam' network. A chapter is dedicated to the origins, history and internal biographies of each movement, with subsequent chapters providing a more general analysis of the impact and continuing development of these religious and political currents. Hamid manages for the most part to aptly strike a balance between examining the granular dynamics of each movement - including internal organisational techniques, ideologies and power struggles - with a more sweeping interrogation of the links between Muslim activism and wider social change for Muslims in Britain. The book therefore succeeds on different levels, documenting both a rich and important series of interconnected histories, whilst also adding to our theoretical understanding of Muslim social and religious change. There are several important themes that emerge as part of this analysis throughout the book.

First, the global dimensions of Muslim activism are often brought to the forefront of the book in a way that captures not just the dynamism of international Islamic discourse but also the crosscutting imbrication of Muslim activism with wider social and political debates. Young Muslims UK, for example, cannot be understood without considering the postcolonial axis that cuts across a panoply of thought, from the anti-colonial impulses of al-Banna and Mawdudi, through to the civil rights communalism of Malcolm X. Hizb ut-Tahrir, meanwhile, emerges from the vanguard politics of socialism - with a line that runs backward through the Syrian Ba'ath party to more traditional forms of Leninist/Trotskyist activity - while Salafi groups mirror the decentralised approach of conservative evangelical Protestantism, including a literalist turn toward primary sources through the mediation of charismatic religious figures. Finally, the Sufi 'Traditional Islam' network - diffuse, open and amorphous - is shown as being discursively embedded within the freewheeling interplay of Western liberalism and cosmopolitanism. This continuing theme therefore builds up into an important, though often publicly-overlooked, theoretical claim: that Islamic activism, in practice and thought, is indelibly bound together with the wider reverberations of modernity.

Second, the book locates Islamic activism within the wider history of social and religious change for Muslims in Britain. Hamid makes sense of organisational change for these movements through a sixpart typology that charts the varying fortunes of each movement (arrival, inception, establishment, fragmentation, renewal and contemporary), although it is perhaps the underlying generational dynamics that are most significant. For example, we witness the political awakening of young second generation activists in the 1980s, marked by a virile utopianism, that gradually matures to become a sophisticated pragmatism, later channelled into the startling institution building of Muslim civil society. In contrast, third generation Muslim youth, in the 2000s, are shown to be more culturally at 
ease than their forebears - taking for granted previous struggles - and therefore more expansive in their effort to carve out an indigenised Islam for wider civic and public life. Through this reading, a biography of Islamic activism is hitched together with the broader sweep of generational change for Muslims in Britain. This analysis, touching as it does upon important points of national debate, makes the wider public failure to recognise these changes only more apparent.

Third, these social changes are exemplified in the evolution of Islamic discourse away from a form of dogmatic Islamism to what Hamid labels - drawing from the work of Asef Bayat - as post-Islamism. This term captures the change in Islamic discourse from an oppositional and alternative model, to one that instead thrives within the structures of British secular and liberal culture. Of course, to a lesser or greater extent groups might oppose or critique certain aspects of this, but post-Islamism suggests that these views have been incorporated within the jostling welter of national conversation. While the Young Muslims UK and Traditional Islam movements might more warmly engage with these structures of open debate, even the exclusivist positions of Hizb ut-Tahrir and Salafi groups are tempered by continuing exposure to the institutions of secular democracy, from the media and academia to policy debates and local politics.

The book therefore shatters a number of myths relating to Islamic activism in the UK. Fundamentally, it problematises ubiquitous, yet hazily defined labels, such as Islamist, Salafi and Sufi. This is done through an emphasis on the internal diversity and shades of thought within such groupings, but also by charting the evolutionary and prismatic qualities of these activist trends. Indeed, a minor criticism of the book might be that the full complexity and richness of these groups is not captured in quite enough detail - it could easily have been doubled in length - although given the hope that this book will have appeal beyond the cantons of academia this is perhaps a smart publication strategy rather than a substantive failing.

Hamid has made a valuable contribution to scholarship relating to Muslims in Britain and has started to fill in one of the many gaps in the field. Methodologically the book represents years of careful research, providing a comprehensive insider-account of these movements. The book is furthermore theoretically-rigorous, while also accessible enough for the introductory reader. One is therefore left hoping that it will receive the wide-reading - especially among journalists and policy makers - that it so richly deserves. 